Lesták Tamás r. alezredes:

\title{
A TÖRÖK HADIIPAR SZEREPE NAPJAINK KONFLIKTUSAIBAN
}

DOI: $10.35926 /$ HSZ.2021.4.3

ÖSSZEFOGLALÓ: A tanulmányban a szerző ismerteti a török hadiipar jelenlegi helyzetét, súlyát, valamint megvizsgálja a török védelmi szektor szereplőinek befolyását nem pusztán Törökországban, de néhány más országban is. Erre a célra három olyan jelenlegi vagy közelmúltbeli fegyveres konfliktust választott, amelyekben török fegyverek, haditechnikai eszközök, sőt a török haderő tagjai is közvetlenül részt vettek, illetve vesznek. Vázlatosan bemutatja a szíriai, a líbiai és a Hegyi-Karabahban folyó küzdelmek során bevetett török fegyverrendszereket, az alkalmazott harceljárásokat és ezek hatását az adott országban folyó fegyveres küzdelem menetére.

KULCSSZAVAk: Törökország, török hadiipar, katonai beavatkozás, Szíria, Líbia, Hegyi-Karabah

\section{BEVEZETŐ}

Törökországot a szakirodalom és a szélesebb közvélemény is az egyik jelentős regionális szereplöként tartja számon a Közel-Kelet tágabban értelmezett térségében. Az ország vezetése az utóbbi néhány évben komoly lépéseket tett e prekoncepció beteljesítése érdekében. Jelen írás célja nem ezeknek a folyamatoknak a tágabb politikai értelmezése, sokkal inkább a konkrét katonai lépések elemzése, különös tekintettel a török hadiipari vállalatok, illetve valamennyi török eredetű fegyver vagy fegyverrendszer külföldi bevetésére. Vizsgálni kívánom mind a fegyverexport (vagy egyéb formájú katonai segítség) révén külföldre került és ott felhasznált török fegyvereket, mind a közvetlenül a török haderő által bevetett eszközök sorsát.

\section{A TÖRÖK HADIIPAR MÚLTJA ÉS JELENLEGI HELYZETE}

Törökország az elmúlt másfél évtizedben rendkívüli mértékủ erőforrásokat allokált a nemzeti védelmi ipar fejlesztésére. Egy átfogó, a már létező hadiipari alap megerősítéséről és egyre nagyobb hozzáadott értékű termékeket előállító ipari szereplők létrehozásáról szóló projekt ${ }^{1}$ keretében² történt az az elörelépés, aminek eredményeként mára számos szektorban a világ

\footnotetext{
1 Turkey's Strategic Vision 2023 Project. TASAM, 2012. http://www.tsv2023.org/index.php/en/ (Letöltés időpontja: 2020. 11.30.)

2 „Törökország 2023-as stratégiai jövőkép projektje” (Türkiye’nin Stratejik Vizyonu 2023 Projesi) elnevezésében az évszám a modern Török Köztársaság létrehozásának százéves évfordulóját jelzi. A projekt a különböző szektorokat érintő, különböző volumenủ és időbeni kifutású fejlesztési programokat mutatja be, amelyek Törökország átfogó fejlesztését célozzák az Erdoğan-kormányzat szándéka szerint. A projekt végső célja, hogy 2023-ra a világ 10 legfejlettebb gazdasága közé emelje Törökországot, és kulcsfontosságú eleme a hazai hadiipar erős ütemủ fejlesztése.
} 
élvonalába tartozik, több esetben jelentős exportkapacitásokkal. A hadiipar fejlesztésénél három fő célt határoztak meg: a számos faktor következtében gyengélkedő gazdaság ${ }^{3}$ stimulálása; a haderő képességeinek megőrzése és új képességek megszerzése; a hadiipari önellátási képesség elérése 2023-ra.

A török hadiipar jelentős múltra tekinthet vissza, az 1980-as évektől kezdődően folyamatos fejlesztések történtek a szektorban. A politikai élet és a hadsereg sajátosan változó viszonyai közepette - és itt nem pusztán a több alkalommal bekövetkezett katonai puccsokra és hatalomátvételi kísérletekre kell gondolni, hanem a török haderő kezdetektől erős gazdasági pozícióira és kötődésére a gazdaság bizonyos szektoraihoz - az első időszakban több más fejlődő országhoz hasonlóan a hagyományos fegyverexportőr államokból, elsősorban az Amerikai Egyesült Államokból és Németországból történtek beszerzések. Ebben az időszakban erős transzatlanti és európai hadiipari kapcsolatok alakultak ki mind a politikai, mind a védelmi ipari szereplők szintjén. ${ }^{4}$ Az 1990-es évek közepétől a 2000-es évekig a védelmi kiadások jelentős mértékben nőttek, természetesen nem függetlenül a katonai vezetés fentebb jelzett közvetlen politikai szerepvállalásaitól, a belső „ellenség” elleni harc pedig - a hosszú évtizedekre visszanyúló politikai-katonai szembenállás a különböző kurd katonai-félkatonai szervezetekkel - szintén felfelé hajtotta a védelmi kiadásokat ezekben az években.

A jelenleg kormányzó Igazság és Fejlődés Pártja $\left(\mathrm{AKP}^{5}\right)$ 2002-es hatalomra kerülését követő első években még a védelmi célú kiadások visszaesését láthattuk, 2005-től azonban megkezdődött a hadiipari kiadások növekedése. Igazán kiugró számokat 2013-tól kezdődően találunk, a Stockholmi Nemzetközi Békekutató Intézet (SIPRI ${ }^{6}$ ) adatai szerint a török fegyverexport 2014-2018 között 170\%-kal nőtt, ${ }^{7}$ ami kiemelkedő eredmény a jelentősebb fegyverexportőr államok között. Az export ilyen mértékü növekedése természetesen feltételezi a mögötte álló hadiipar fejlödését is.

A török vállalatok - mint oly sok más hasonló esetben - kezdetben külföldi fegyverek (a NATO tagjaként természetszerüleg elsősorban nyugati fegyverek) importjában vettek részt, ezt követte az egyes részegységek hazai összeszerelése, majd pedig a külföldi licenc alapján történő hazai gyártás, akár már teljes fegyverek esetében. ${ }^{8}$ A legnagyobb török vállalatok sikeres és megbízható összeszerelői, beszállítói tevékenysége nyitotta meg az utat a védelmi kapacitások minőségi fejlesztéséhez. Az 1990-es évek végétől felmerült a lehetőleg minél önállóbb török védelmi ipari kapacitások megteremtésének igénye, elsősorban az importfüggőség csökkentése okán. Ez a cél hangsúlyosan és megfelelő költségvetési források

3 Törökország gazdasági teljesítményének részletes elemzése terjedelmi okokból sem célja e tanulmánynak, ugyanakkor a hadiipari események megértéséhez szükséges ismerni a jelenlegi gazdasági háttér legfontosabb szempontjait. Ezek: a török nemzeti fizetőeszköz rendkívüli mértékủ gyengülése és volatilitása az elmúlt években; különböző szintű és kiterjedésű (elsősorban amerikai és EU) gazdasági szankciók; a török monetáris politika teljesítményét illető befektetői bizonytalanság; növekvő munkanélküliség; a nemzetközi ,agyelszívás” jelenségének erősödése; a külpolitika általános irányvonalának hazai és nemzetközi befektetöket egyaránt elbizonytalanító folyamatos változása.

4 Anouck Gabriela Corte Réal-Pinto: Une exception néolibérale? Le projet de turquification de l'armement. Revue international de politique de développement, 08. 09. 2017. https://journals.openedition.org/poldev/2456 (Letöltés idöpontja: 2020. 11. 30.)

5 Adalet ve Kalkınma Partisi.

6 Stockholm International Peace Research Institute.

7 Turkey tops the international weapon export rating. TRT World, 12. 03. 2019. https://www.trtworld.com/turkey/ turkey-tops-the-international-weapon-export-rating-24880 (Letöltés időpontja: 2020. 12. 01.)

8 Kezdetben jellemzően különféle szárazföldi jármüveket, elsősorban páncélozott szállító harcjárműveket gyártottak a török vállalatok. 
allokálása mellett az AKP kormányra kerülése után, a 2000-es évek közepétől a hivatalos célok közé is bekerült.

A török védelmi ipar felépítése a legutóbbi időkig kétségkívül előnyös keretet biztosított a védelmi fejlesztések sikeres véghezviteléhez. 1985-ben hozták létre a Védelmi Ipari Elnökséget $\left(\mathrm{SSB}^{9}\right)$ mint a védelmi ipar állami támogatását képviselö és a beszerzéseket koordináló ernyőszervezetet, majd pedig 1987-ben jött létre a Török Fegyveres Erők Alapítványa $\left(\mathrm{TSKGV}^{10}\right)$, mely a szektor híres szereplöjévé vált hosszú évtizedekre. ${ }^{11} \mathrm{~A}$ TSKGV azóta is számos kulcsfontosságú állami és privát vállalatban rendelkezik tulajdoni hányaddal.

A török védelmi ipar legfontosabb szereplöi: ${ }^{12,13}$

- Aselsan - elsősorban szárazföldi fegyverrendszerek integrációjával, modernizációjával, valamint a C4ISR ${ }^{14}$ területén tevékenykedik;

- Roketsan - nem irányított és irányított tüzérségi lőszerek, rakétarendszerek és ballisztikus eszközök fejlesztését végzi;

- Havelsan - szoftverek, szimulátorok fejlesztője, rendszerintegrátor;

- Aspilsan és İşbir - a védelmi energetikai szektorban müködnek;

- TUSAŞ ${ }^{15}$ (repülögépipar);

- $\mathrm{BMC}^{16}$ (szárazföldi jármüvek);

- MKEK ${ }^{17}$ (löszergyártás);

- Kale, Sarsılmaz, YDS (repülőgép-hajtómü, kézifegyvergyártás, ruházat/lábbeli).

A török hadiipar egyik legerősebb szegmensét napjainkban is a szárazföldi jármüvek és fegyverrendszerek képviselik, a fegyveres erők (és a belbiztonsági alakulatok is) ezen a területen szinte teljesen hazai eszközöket használnak. Ahogy İsmail Demir, az SSB elnöke fogalmazott: „A szárazföldi rendszerek az a terület, ahol a leginkább látjuk a befektetéseink értékét, mivel a külföldi függöségünk minimalizálva lett, és nagyon széles termékportfólióval rendelkezünk."18 Az első exportsikerek is e területen születtek: a vevőkört kezdetben elsősorban közel-keleti és délkelet-ázsiai államok jelentették, később ez kiegészült európai NATO-tagállamokkal.

A török hadiipar fejlödése a 2010-es években újabb területeken vált kézzelfoghatóvá, mindenekelőtt a repülögépipar és az elektronika, valamint a tüzérségi eszközök terén. Ezt jól példázza, hogy - a SIPRI adatai szerint - a fentebb már említett vállalatok közül jelenleg

\footnotetext{
9 Savunma Sanayii Başkanlı̆̆ 1 .

10 Türk Silahlı Kuvvetlerini Güçlendirme Vakfi.

11 Anouck Gabriela Côrte Réal-Pinto: A Neo-Liberal Exception? The Defence Industry 'Turkification' Project. Revue international de politique de développement, 8/2017., 299-331. https://journals.openedition.org/poldev/2456 (Letöltés időpontja: 2020. 11. 30.)

12 Alican Tekingunduz: Turkey's growing defence industry. TRT World, 04. 05. 2018. https://www.trtworld.com/ turkey/turkey-s-growing-defence-industry-17014 (Letöltés időpontja: 2020. 11. 22.)

13 Turkish-Indonesian relations deepen with defense industry cooperation. Nordic Monitor, 13. 11. 2020. https:// nordicmonitor.com/2020/11/turkey-indonesia-relations-deepen-with-defense-industry-cooperation/ (Letöltés időpontja: 2020. 11. 28.)

${ }^{14}$ Command, Control, Communications, Computers, Intelligence, Surveillance and Reconnaissance - vezetés, irányítás, kommunikáció és számítástechnika, hírszerzés, megfigyelés és felderítés.

15 Türk Havacılık ve Uzay Sanayi A.Ş. - Török Légi- és Üripari Zrt.

${ }^{16}$ British Motor Company Turkey.

17 Makina ve Kimya Endüstrisi Kurumu - Gépipari és Vegyipari Ipartestület.

${ }^{18}$ How Turkey became one of the world's leading manufacturers of weapons systems. Defense News, 21. 07. 2020. https:/www.defensenews.com/native/turkish-defence-aerospace/2020/07/21/how-turkey-became-one-of-theworlds-leading-manufacturers-of-weapons-systems/ (Letöltés időpontja: 2020. 11. 30.)
} 
már hét ${ }^{19}$ - közöttük az Aselsan és a TUSAŞ - is bekerült a világ 100 legnagyobb védelmi ipari szereplöje közé, míg 2010-ben ez a szám még csak egy volt. Törökország globálisan a 14. legnagyobb fegyverexportőrré vált. ${ }^{20} \mathrm{Ez}$ az az időszak, amikor egyre több ország és vevő fedezte fel magának a török vállalatok kínálatát, a török ipar egyre többféle eszközt, fegyverrendszert tudott elöállítani, és ami jelentős előrelépés volt: ezek a termékek egyre több hazai hozzáadott értéket képviseltek olyan részterületeken is, amelyeken korábban jellemzően nyugati vállalatok uralkodtak (pl. irányított tüzérségi lövedékek, repülőgépelektronika). Ékes példája ennek Törökország magas szintü részvétele az amerikai Lockheed Martin F-35 típusú repülőgépének fejlesztési programjában.

A rendkívül magas technológiai színvonalat megkövetelö ipari részvételnek több szintje létezik. Törökország, illetve több mint 30 török vállalat ún. Tier 3-as szintü partnerként ${ }^{21}$ vett részt az említett programban. Ez azt jelentette, hogy számos fontos részegység fejlesztésében aktívan közremüködtek, beleértve a kutatás-fejlesztési tevékenységet is. Sőt az ország ritka kivételek egyikeként födarabot is gyártott (volna) ${ }^{22}$ az F-35-ös repülögéphez. Az exportsikerek $^{23}$ mellett nagyon fontos eredmény, hogy Törökország a korábbi mintegy $70 \%$-os importhányadát nagyságrendileg 30\%-ra csökkentette. ${ }^{24}$ A török védelmi ipar mindezeken felül abba a viszonylag szük körbe tartozónak is mondhatja magát, amely országok képesek magas szinten felderítő és felfegyverzett pilóta nélküli repülőgépek előállítására. E tény az utóbbi évek összes jelentős török hadmúveletében szerepet játszott.

Törökország hadiipara tehát rendkívül nagy fejlődési utat járt be az elmúlt 2-3 évtizedben, és mára egy magas szintű, magas hozzáadott értékű termékeket előállító szektorrá vált, amely jelentősen hozzájárul a nemzetgazdaság növekedéséhez. Vevői között pedig fejlődő és fejlett államokat egyaránt megtalálunk szinte valamennyi haderőnem esetében. A védelmi szektor ezenfelül politikai szempontból is kulcsfontosságúvá vált az elmúlt években, hiszen az Erdoğan-adminisztráció egyik tartóoszlopaként funkcionál. Különösen igaz ez napjainkban, amikor az ország gazdasági és külpolitikai problémáit legalább részben képesek elfedni a védelmi szektor újabb és újabb pozitív gazdasági eredményei.

A fentiekben felvázolt fejlödési pálya azonban a jelek szerint nem töretlenül folytatódik. Már 2019-től kezdődően mutatkoztak jelei a fegyverexport visszaesésének. Ennek okai meglehetősen összetettek. Mindenekelőtt az importfüggőség jelentkezik mint korlátozó tényező. Bár a török védelmi szektor jelentős eredményeket ért el az importfüggőség csökkentése érdekében, de az utóbbi időben előtérbe kerülő magas technológiai szintet képviselö, egyre komplexebb fegyverrendszerek esetében nem lehetséges a teljesen hazai gyártás megvalósítása - a teljes értékláncot tekintve. Minden ilyen termék esetében akad egy olyan részegység, alkatrész, komponens, amely valamely beszállítótól származik, sok esetben külföldről.

19 Több mint Izraelnek, Svédországnak, Japánnak és Oroszországnak összesen.

20 Turkey among top 100 in global arms industry. TRK World, 11. 12. 2018. https://www.trtworld.com/turkey/ turkey-among-top-100-in-global-arms-industry-22395 (Letöltés időpontja: 2020. 12. 01.)

${ }^{21}$ Az F-35-ös programban a részvétel szintje szerint különböztetik meg a partnereket a részt vevő vállalatok nagysága, a saját invesztált know-how mértéke, a kutatás-fejlesztésben történő részvétel aránya és a végszerelés, gyártás volumene és jellegzetességei alapján.

22 Az F-35-ös programból történő kilépés/kimaradás, valamint a kapcsolódó politikai és fegyverbeszerzési döntések teljes folyamatát terjedelmi okokból nem ismertetem.

23 Arms exports (SIPRI trend indicator values) - Turkey. The World Bank, 2020. https://data.worldbank.org/indicator/ MS.MIL.XPRT.KD?locations=TR (Letöltés időpontja: 2020. 12. 01.)

${ }^{24}$ Ferhat Gurini: Turkey’s unpromising defense industry. Carnegie Endowment for International Peace, 09. 10. 2020. https://carnegieendowment.org/sada/82936 (Letöltés időpontja: 2020. 11. 21.) 
Törökország vonatkozásában ez a helyzet például egy olyan helikopter esetében, amelyet Pakisztánnak kellett volna leszállítania az adott vállalatnak, az Amerikai Egyesült Államok engedélyét azonban nem kapták meg ehhez, ${ }^{25}$ így a szerződést nem tudják teljesíteni.

Egy másik példa az utóbbi idők egyik legnagyobb, jelképessé vált török védelmi fejlesztési projektje az Altay harckocsi kifejlesztése és rendszerbe állítása. Bár a típus első példányait már csapatpróbán tesztelik (sőt egyes sajtóhírek szerint több külföldi katonai müveletben is bevetették azokat), a végleges, teljes kapacitással történő rendszeresítés bizonytalan ideig késik, ismételten egy külföldi eredetü részegység miatt. Ez pedig a harckocsi hajtáslánca, amelyet egy német vállalat fejleszt és szállítana, ami azonban Törökország közelmúltbeli külföldi katonai múveletei miatt - vagyis politikai okból - felfüggesztette a részegység szállítását. Egy harmadik példa pedig a szintén török fejlesztésű Akıncı drón, melynek hajtómüvét egy ukrán vállalat szállította, de jelenleg technológiai és szellemi tulajdoni aggályok okán vonakodik a hajtómü további biztosításától. ${ }^{26}$

A politikai eredetủ akadályokra további példa a török haditengerészeti erök egyébként igen erőltetett ütemü fejlesztését övező fennakadások kérdése. A rendkívül modern hajóegységekkel felszerelt, illetve több beszerzési programot ${ }^{27}$ is futtató török állam ellen több európai ország (pl. Németország, Spanyolország, Norvégia, Finnország, Csehország) különböző szintü gazdasági szankciókat és fegyverszállítási embargót rendelt el. Ezekben az esetekben az elmúlt évtizedek minden igyekezete ellenére Törökország nem képes önállóan megfelelő színvonalú termékek gyártására, elsősorban a termékek rendkívüli komplexitása okán. ${ }^{28}$

Szintén nagyon komoly problémát okoz a védelmi szektornak az agyelszívás jelensége, mely a 2016-os meghiúsult puccskísérletet követően erőteljesebben jelentkezik. ${ }^{29} \mathrm{~A}$ védelmi szektort elhagyók nagy része pedig éppen Németországba vagy az Amerikai Egyesült Államokba távozott. E jelenség súlyosbodására lehet számítani, mivel a jelenlegi politikai légkör és az ún. gülenista mozgalom ${ }^{30}$ tagjai elleni hazai intézkedések tovább erodálhatják a szektor humán eröforrásait.

Az exportkiesést a hazai megrendelések pótolhatják, de a gazdaság súlyos problémái kétségessé teszik, hogy középtávon mennyi ideig lesz tartható a jelenlegi fejlesztési ütem. Természetesen ilyen irányú politikai döntés esetén továbbra is folytatható az eröltetett ütemü hazai fegyverkezés, valamint a külföldi katonai müveletekben elszenvedett veszteségek pótlása is potenciális megrendelésállományt jelenthet a szektor szereplői számára, de a hosszú távú ütem tartása 2020 végén legalábbis kétségesnek tünik.

\footnotetext{
${ }_{25}$ Mivel a helikopter hajtómüve részben amerikai fejlesztésü, ezért annak további exportjához szükséges Washington engedélye is.

26 Turkey records significant drop in defense industry exports in January-August 2020. Nordic Monitor, 25. 09. 2020. https://nordicmonitor.com/2020/09/turkey-records-significant-drop-in-defence-industry-exports-in-januaryaugust-2020/ (Letöltés időpontja: 2020. 11. 15.)

27 Például a Barbaros- és Yavuz-osztályú fregattok, illetve a Kılıç-osztályú gyors támadó hajóegységek is német eredetüek.

28 Gurini: i. m.

${ }^{29}$ Csak 2019-ben mintegy 330 ezer személy hagyta el Törökországot a Nemzetközi Migrációs Szervezet (IOM) adatai szerint.

${ }^{30}$ Abdullah Gülen vallási és politikai vezető által külföldön fenntartott politikai, társadalmi mozgalom.
} 


\section{Bonyolult hadszíntér, komoly török beavatkozás - Szíria}

2020-ban a török politikai vezetés egy addig példátlan lépésre szánta el magát a rendkívül bonyolult és turbulens szíriai események kapcsán, mégpedig fegyveres alakulatokkal történő közvetlen beavatkozásra a szíriai hadszíntér területén. A beavatkozás ráadásul nem pusztán a napjainkban „,megszokott” korlátozott légi háború eszközeivel, hanem jelentős számú török katona Észak-Szíriába történő vezénylésével, vagyis a szárazföldi haderőnem bevonásával történt. A hadműveletek teljes kronologikus bemutatására jelen írás terjedelmi okokból nem vállalkozik, pusztán a hadszíntéren bevetett török fegyverek és fegyverrendszerek leltárba vételével szeretném érzékeltetni a török hadiipar korábban vázlatosan bemutatott termékeinek gyakorlati teljesítményét, illetve ezeknek az eszközöknek a hatását az adott hadmüveletekre.

Törökország már a szír polgárháború 2011-es kitörése óta közvetett eszközökkel részt vett a konfliktusban, eredendően az Aszad-kormány elleni feleket támogatva különböző szinten és különböző eszközökkel. Ezeket közvetlen fegyveres beavatkozások követték 2016-tól kezdődően, ${ }^{31}$ melyek eredményeképpen 2020-ra Észak-Szíria egy jelentős része török katonai ellenőrzés alá került. ${ }^{32}$ A közvetlen török beavatkozásra vonatkozó döntést hivatalosan a Szíriában aktív különböző kurd fegyveres alakulatok és ezek vélt vagy valós, Törökország biztonságára fenyegetést jelentő tevékenysége váltotta ki. A cél egy biztonságos ütközőzóna kialakítása volt, amely lehetőséget ad a szíriai civil lakosság elhelyezésére, emellett természetesen a közvetlen török katonai célkitűzéseket és a közvetett politikai elképzeléseket is segítheti közép- és hosszú távon.

2020 év elején újabb török csapaterősítések történtek, ${ }^{33}$ melyek vizsgálatával jó rálátást nyerhetünk arra, hogy a török hadiipar milyen eszközei is kaptak/kapnak szerepet a szír hadszíntéren. A legfrissebb, megerösített információk szerint az alábbi eszközök voltak, illetve vannak jelen Szíria északnyugati és északkeleti határvidékein:

- M60A3 Sabra harckocsi: az Israeli Military Industries vállalat által modernizált és Törökországnak 2005-től leszállított közepes harckocsi. 170 db-ot már török vállalatok újítottak fel. A 2020. tavaszi csapaterösítések keretében vetették be Szíriában, elsősorban csapatvédelmi feladatkörben, nem támadó szerepben. ${ }^{34}$

- Altay harckocsi: a török BMC vállalat által fejlesztett ${ }^{35}$ nehéz harckocsi a szárazföldi haderőnem egyik legújabb eszköze, mintegy 300 db gyártásáról szóló szerződést

31 2016-ban még csak egy-egy város vagy terület iszlamistáktól történő megtisztítására került sor; 2017-ben az Idlíb kormányzóság területén az orosz haderővel együttmüködésben; 2018-ban az Olajág müvelet keretében Északnyugat-Szíria területén már átfogóbb műveletek történtek a Szabad Szír Hadsereg nevű ellenzéki alakulatokkal együtt; 2019-ben a még nagyobb volumenű Tavaszi Béke művelet keretében török csapatok bevonulása északkelet Szíriába; és végül 2020 márciusában a Tavaszi Pajzs művelet keretében újabb beavatkozás a szíriai kormányerők ellen.

32 Turkish Army makes major military deployment to Syria’s Idlib. Daily Sabah, 16. 10. 2020. https://www. dailysabah.com/world/syrian-crisis/turkish-army-makes-major-military-deployment-to-syrias-idlib?gallery_ image= undefined\#big (Letöltés időpontja: 2020. 11. 28.)

33 Ana Rodriguez: Turkey shows military muscle in Syria with the shipment of 35 new military vehicles. Atalayar, 05. 05. 2020. https://atalayar.com/en/content/turkey-shows-military-muscle-syria-shipment-35-new-militaryvehicles (Letöltés időpontja: 2020. 11.30.)

34 Turkish military arsenal in Syria. Jusoor for studies, 02. 03. 2020. https://jusoor.co/details/Turkish\%20Military\%20 Arsenal\%20in\%20syria/584/en (Letöltés időpontja: 2020. 11. 29.)

35 A szakirodalom véleménye megoszlik arról, hogy a harckocsi teljesen eredeti török fejlesztés eredménye-e, vagy pedig az alapot jelentő, a koreai Hyundai Rotem vállalat által kialakított dizájn török továbbfejlesztéséről van-e szó. Török források természetesen teljesen saját fejlesztésként hivatkoznak rá. 
írtak alá 2018-ban. A harckocsi három verzióban fog készülni, közülük egy személyzet nélküli lövegtoronnyal felszerelt változat lesz. Egyes adatok szerint ez a világ legdrágább harckocsifejlesztési programja a maga több mint 13 millió dolláros darabárával. A fejlesztési program egyes részegységeit érintő importfüggőségből eredő problémákról korábban már volt szó. Jelentések szerint mindössze néhány egységet vetettek be Szíriában, elsősorban csapatpróbajelleggel, az esetleges technikai ,gyermekbetegségek" felszínre hozatala céljából, melyek jelenléte és megoldása napjaink valamennyi komplex fejlesztésénél természetes. ${ }^{36}$

- M113 páncélozott szállitó jármü: az eredetileg amerikai lánctalpas jármüvet török vállalatok modernizálták a vonatkozó NATO-követelményeknek megfelelően. A jármüvet csapatszállító feladatkörben vetették be, viszonylag korlátozott számban. ${ }^{37}$

- Cobra kommunikációs jármü: az Otokar török vállalat által gyártott kerekes többfunkciós taktikai járművet ${ }^{38}$ Szíriában kommunikációs célokra, illetve földi telepítésü megfigyelő radarrendszerek müködtetésére vetették be az irányított tüzérségi csapások pontosságát javítandó, igen nagy hatásfokkal.

- SERHAT II tüzérségi felderitôradar: az Aselsan által gyártott radarrendszer az aktív ellenséges tüzérség helyzetének meghatározására szolgál, elősegítve ezzel a saját tüzérség vagy légierő ellentevékenységét. ${ }^{39} \mathrm{~A}$ könnyü jármüveken is bevethető rendszert Szíriában rendkívül nagy hatékonysággal alkalmazták, gyors válaszcsapásokat lehetővé téve a szír kormányerők tüzérségi állásaira, ezzel tüzérségi fölényt létrehozva a török hadsereg müveleti területén.

- Boran tüzérségi eszköz: az MKEK által gyártott könnyü, légi szállítású, közepes lőtávolságú tüzérségi löveg, melyet kifejezetten kis létszámú alegységek akcióinak támogatására hoztak létre..$^{40}$ Ilyen jellegü müveletekben vett részt Szíriában is, elsősorban határ menti, illetve egy-egy település elfoglalására indított akciók során.

- TRG-300 Kaplan rakéta-sorozatvető: a Roketsan által gyártott saját fejlesztésü eszköz lőtávolsága 80-120 km, tehát az ellenség mélységi célpontjai eredményesen támadhatóak vele. ${ }^{41}$ Az eszköz a precíziós tüzérségi fegyverek közé tartozik, ennek megfelelően a mélységben, bőven az ellenséges vonalak mögötti megerősített vezetési pontokat, katonai létesítményeket (elsősorban a szíriai kormányerők létesítményeit) támadták vele.

- T-155 Firtina önjáró löveg: az MKEK által kifejlesztett lánctalpas önjáró löveg 155 mmes NATO-lőszerek tüzelésére alkalmas, korábbi saját fejlesztések evolúciójaként rendszeresítették a török szárazföldi haderőnemnél. ${ }^{42}$ Nagy tűzgyorsasága és pontossága okán a török haderő viszonylag nagy számban alkalmazta, elsősorban az Idlíb kormányzóságbeli Taftanáz légibázis környékén települve.

- T-122 Sakarya rakéta-sorozatvetö: a Roketsan terméke a mintegy 40 km-es lőtávolságán belül képes nagy tüzgyorsaságú csapásmérésre. ${ }^{43}$ Jelentések szerint a török erők

\footnotetext{
36 Turkish Defense Industry Product Catalogue. Presidency of Defense Industries, Ankara, 2019, 20. https://www. ssb.gov.tr/urunkatalog/en/ (Letöltés időpontja: 2021. 04. 02.)

${ }^{37}$ Uo. 22 .

${ }^{38}$ Uo. 25.

39 Turkish military arsenal in Syria.

40 Turkish Defense Industry Product Catalogue, 237.

${ }^{41}$ Turkish military arsenal in Syria.

42 Uo.

43 Turkish Defense Industry Product Catalogue, 211.
} 
Idlíb környékén, illetve a harcok kezdeti szakaszában a határ menti összecsapásokban is széleskörüen alkalmazták, érzékeny veszteségeket okozva az ellenségnek.

- Bora harcászati ballisztikus rakéta: a szintén a Roketsan-termék rakétarendszer hadszíntéren belüli célpontok nagy távolságból történő megsemmisítésére szolgál. Az ellenség kiemelt, nagy értékü eszközeinek, létesítményeinek, esetleg katonai-politikai vezetésének kiiktatására alkalmazható. ${ }^{44}$ Szíriában 2020 közepétől telepítették, bevetésének pontos körülményeiről azonban nincsenek megbízható információk.

- Bayraktar TB2 pilóta nélküli repülöeszköz: a Baykar által gyártott ún. MALEkategóriájú ${ }^{45}$ felfegyverzett drón. ${ }^{46}$ Szinte valamennyi térségbeli török hadmüveletben részt vesz; a sajtóban is híressé/hírhedtté vált repülöeszköz rendkívül hatékony fegyvernek bizonyult Szíriában is. A felderítéssel és tüzérséggel együtt igen pontos légicsapásokat volt képes mérni akár statikus, akár mozgó célpontokra, komoly veszteségeket okozott a szír kormányerőknek, sőt több jelentés szerint az orosz haderő által biztosított Pancir 1 típusú csapatlégvédelmi eszközök és Sz-300-as légvédelmi rakétaütegek ellen is sikeresen alkalmazták. A szíriai, líbiai és kaukázusi müveleti tapasztalatok (ezekről részletesen lásd a további fejezeteket) azt mutatják, hogy igen ellenálló a különböző orosz és kínai katonai, illetve kereskedelmi eredetü elektronikus zavarórendszerekkel szemben is.

- Anka S pilóta nélküli repülöeszköz: a TUSAŞ vállalat terméke ez a MALE-kategóriájú felderítődrón. Az ellenséges csapatmozgások felderítésére, célazonosításra és megjelölésre, valamint a tüzérségi csapások irányítására és azok utólagos kiértékelésére ${ }^{47}$ használták a szíriai hadszíntéren, szoros együttműködésben a különböző felfegyverzett típusokkal.

- T129 ATAK harci helikopter: az AgustaWestland (ma Leonardo) céggel közösen fejlesztett eszközt a TUSAŞ gyártja. ${ }^{48}$ A harci helikopter rendkívül sikeres belföldi és külföldi müveletekben egyaránt. A forgószárnyassal komoly harci tapasztalat gyülemlett fel az elmúlt évtized során, elsősorban a kurd fegyveres szervezetek elleni müveletekben. Ennek megfelelően természetes, hogy feltűnt a Szíriában harcoló alakulatok kötelékében is már az első időszakban. Mindenekelött könnyű vagy páncélozott földi célpontok ellen vetették be, illetve fegyveres felderítést is gyakran végeztek az elörenyomuló szárazföldi erők védelme érdekében. A szintén török gyártmányú Cirit (hatótávolsága 1,5-8 km, átméröje $70 \mathrm{~mm})$ és UMTAS $(0,6-8 \mathrm{~km}$, illetve $180 \mathrm{~mm})$ levegö-felszín osztályú rakétákkal - lézeres célmegjelöléssel - precíziós csapásmérésre is alkalmas. Ilyen bevetésekröl több, a közösségi médiában felbukkant felvétel is tanúskodik.

- Koral elektronikai hadviselési rendszer: az Aselsan mobil jármüvekre telepíthető elektronikai zavaró-, felderítő- és lefogórendszere rendkívül fontos elemét képezte a bevetett török fegyverrendszereknek. Részt vett az ellenséges légvédelmi egységek beazonosítását és lefogását célzó müveletekben, valamint a török erők ellen bevetett légi egységek elleni zavaró tevékenységben. ${ }^{49}$ Már 2016-tól jelen volt a szír hadszíntéren, fokozatosan egyre nagyobb számban. Jelenleg ezek az egységek a török hadsereg által ellenőrzött teljes területen megtalálhatóak.

\footnotetext{
44 Turkish military arsenal in Syria.

${ }^{45}$ Medium Altitude Long Endurance - közepes repülési magasságú, hosszú repülési idejü.

46 Turkish Defense Industry Product Catalogue, 145.

47 Uo. 142.

48 Uo. 140.

49 Turkish military arsenal in Syria.
} 
- Kirpi páncélozott csapatszállító jármü: a BMC vállalat által gyártott kerekes csapatszállító jármü az egyik legrégebbi és legsikeresebb török szárazföldi jármü, rengeteg változatban készül. ${ }^{50}$ Alapvető résztvevője minden külföldi török hadmüveletnek, így a szír hadszíntéren is nagy számban található meg. A bevetett török katonák számának növekedésével e jármúvek is egyre nagyobb számban kapnak szerepet a csapatok mozgatásában.

- Ejder Yalçin gyalogsági harcjármü: a Nurol Makina vállalat által gyártott páncélozott gyalogsági harcjármüveket ${ }^{51}$ a harcok kezdeti szakaszában, viszonylag kis számban vetette be a török hadsereg a szír hadszíntéren, sajtójelentések szerint nem túl kedvező eredménnyel, több veszteséget is elkönyvelve. A járművet az Iszlám Állam erői sikerrel támadták különböző páncéltörő eszközökkel, így a török hadvezetés viszonylag gyorsan visszavonta azokat, és a vállalat megkezdte a műveleti tapasztalatok alapján történő átépítést/továbbfejlesztést.

(Érdekesség, hogy a Nurol Makina vállalat termékeinek magyar vonatkozását is megtalálhatjuk a közelmúltban a hazai védelmi beszerzésekről szóló híradásokban. ${ }^{52}$ A Magyar Honvédség a Honvédelmi és Haderőfejlesztési Program keretében a vállalat két termékének szállítására is szerződést kötött: a maximálisan 11 fő szállítására képes Ejder Yalçin - Magyarországon Gidrán néven rendszeresítik a típust - páncélozott gyalogsági harcjármüből, valamint a kisebb, legfeljebb 7 fő szállítására szolgáló NMS járművekből összesen $250 \mathrm{db}$ beszerzéséről ${ }^{53}$ - illetve a későbbiekben a megrendelt mennyiség egy részének magyarországi, kaposvári összeszereléséről és továbbfejlesztéséről - született döntés. A jármüvek beszerzése részben egy könnyülövészdandár felszerelésére vonatkozó NATOvállalás teljesítését szolgálja majd a rendszeresítést követően. A jövőbeli továbbfejlesztésben a török gyártó mellett a német Rheinmetall vállalat vesz részt. $)^{54}$

Fentiekből megállapítható, hogy a török védelmi szektor saját fejlesztésű termékeinek széles spektruma vesz részt a szíriai hadmüveletekben. A bevetett eszközök egy része magas technikai színvonalat képvisel, és azok jelentős mértékben hozzájárultak a szíriai kormányerök (sőt esetenként fejlett orosz rendszerek) elleni müveletek sikeréhez. Mindez végső soron azt eredményezte, hogy a török katonai vezetés által kitüzött célt - nevezetesen egy török ellenőrzésủ észak-szíriai ütközőzóna kialakítását - sikerült elérni, és ebben az ellenséges erök nem tudták jelentősen akadályozni vagy késleltetni a török haderő katonáit. A pontos török veszteségekről - mint ahogyan az napjaink konfliktusaiban sajnálatos módon megszokott - nem rendelkezünk megbízható adatokkal, elsősorban a szárazföldi erők szenvedtek komolyabb veszteségeket még az északi területekre történő benyomulás kezdeti szakaszában. Jelenleg a harcok kevésbé aktív, inkább területbiztosító szakasza zajlik. A török haderő tagjai ezeket a feladatokat alapvetően sikeresen tudják ellátni.

${ }^{50}$ Turkish Defense Industry Product Catalogue, 28.

${ }^{51}$ Uo. 26.

52 Magyar helyett török harcjárműveket vásárolt a honvédség. Totalcar, 2020. 10. 31. https://totalcar.hu/magazin/ hirek/2020/10/31/magyar_helyett_torok_harcjarmuveket_vasarolt_a_honvedseg/(Letöltés időpontja: 2020. 11. 29.)

${ }^{53}$ Huszák Dániel: Bejelentették: több mint 300 újfajta katonai jármüvet szerez be a Honvédség. Portfolio, 2020. 12. 21. https://www.portfolio.hu/global/20201221/bejelentettek-tobb-mint-300-ujfajta-katonai-jarmuvet-szerezbe-a-honvedseg-462752 (Letöltés időpontja: 2020. 12. 03.)

${ }^{54}$ Huszák Dániel: Vadi új katonai jármüvek gyártása indul meg Magyarországon. Portfolio, 2020. 12. 18. https:// www.portfolio.hu/global/20201218/breking-vadi-uj-katonai-jarmuvek-gyartasa-indul-meg-magyarorszagon-462484 (Letöltés időpontja: 2020. 12. 04.) 


\section{KLASSZIKUS FEGYVEREXPORT VAGY KÖZVETLEN BEAVATKOZÁS? - A LÍBIAI KALAND}

A török hadiipar külföldi befolyásának, illetve hatásának vizsgálatához mindenképpen szót kell ejteni Líbiáról is. Az észak-afrikai ország 2011 utáni, Moammer Kadhafi halálát követő történelme tulajdonképpen polgárháborús vagy egyéb formájú fegyveres összetüzéseknek, továbbá az ország több részre szakadásának folyamatos története. A permanens polgárháborús állapotok mellett azonban számos külső szereplő kapott és kap változó mértékű szerepet az ország politikai és katonai eseményeinek alakításában. Ezek a szereplők ${ }^{55}$ egyre komolyabb katonai befolyást is szereznek az országban, legyen szó akár fegyverszállításról, belső frakciók, tömbök támogatásáról, vagy éppen közvetlen katonai beavatkozásról. Törökország e szereplők közül is kiemelkedik az utóbbi év eseményeinek tükrében, hiszen egyre aktívabban és saját célkitüzései szempontjából egyre hatékonyabban tud beavatkozni a líbiai katonai események alakulásába. Az ottomán állam Líbia két, állami jegyekkel leginkább rendelkező entitása $^{56}$ közül a nemzetközileg elismert kormányt (GNA) támogatja a konfliktus során.

A török beavatkozás e tanulmányban vizsgált példáink közül időben a legközelebbi, mivel a török fegyveres erők közvetlen líbiai szerepvállalása 2020 elején vette kezdetét. ${ }^{57}$ Törökország ezt megelőzően is részt vett a konfliktusban, de elsősorban katonai tanácsadókkal, hírszerzési információkkal és kiképzési segítséggel.

Ankara közvetlen katonai beavatkozásának fő célja a szakértők szerint az ország fontos nyersanyagaihoz történő hozzáférés, illetve a Földközi-tenger keleti medencéje tengeri határainak ellenörzése ${ }^{58}$ volt. Emellett török szempontból fontos Egyiptom és az Egyesült Arab Emírségek észak-afrikai befolyásának korlátozása, illetve csökkentése is.

A 2020. januári telepítések kezdetben még főként csapatszállítást és hadianyag-szállítást jelentettek. ${ }^{59}$ Márciusban kezdődött a tulajdonképpeni hadmüvelet, mely a Béke Vihara nevet kapta. A török csapatok - kisebb részben szárazföldi alakulatok, nagyobb részben a légi és a tengeri haderőnem egységei - viszonylag rövid idő alatt elősegítették a GNA erőinek elöretörését, több város visszafoglalását, valamint súlyos veszteségeket okoztak Halifa Haftár tábornok erőinek, sőt egyes jelentések szerint a török pilóta nélküli repülőeszközöknek Líbiában is sikerült korszerủ orosz légvédelmi eszközöket megsemmisíteni. ${ }^{60} \mathrm{Az}$ év közepére a hathatós török támogatásnak köszönhetően sikerült Tripoli visszafoglalása is Haftár erőitől. Az erőviszonyok a nyári hónapokra olyan mértékben megváltoztak a török oldal javára, hogy török célpontok ellen más külső szereplők részéről több légicsapásra is sor került, ${ }^{61}$ melyek célja a török be-

55 A legfontosabb külső aktorok: Törökország, Egyiptom, Egyesült Arab Emirségek, Oroszország, Franciaország, Amerikai Egyesült Államok.

56 Jelenleg két „,kormány” létezik Líbiában: az egyik az elsősorban a keleti országrészt irányító Líbiai Nemzeti Hadsereg (Libyan National Army - LNA), a másik a nyugati területeket ellenőrző ún. Nemzeti Egyetértés Kormánya (Government of National Accord - GNA). A nemzetközi közösség ez utóbbit ismeri el, de a különböző külföldi támogatók megoszlása sokkal bonyolultabb képet mutat.

${ }^{57}$ A Török Nagy Nemzetgyülés 2020. január 2-i döntésével hagyta jóvá a haderö Líbiában történő bevetését, egyéves időtartamon belül, mely a gyakorlatban három nappal később kezdetét is vette.

${ }^{58}$ Az ezt a célt is tartalmazó szélesebb programot az ún. Kék Anyaföld Doktrína tartalmazza.

59 Adam Nathan: Cargo ship loaded with Turkish military vehicles arrives in Tripoli. Alarabiya News, 20. 05.2020. https:/english.alarabiya.net/News/north-africa/2019/05/19/Cargo-ship-loaded-with-Turkish-military-vehiclesarrives-in-Tripoli (Letöltés időpontja: 2020. 11. 30.)

${ }^{60}$ Mohammad Pervez Bilgrami: How Turkey crushed UAE’s gambit in Libya. Agenfor International, 01. 06. 2020. https:/www.agenformedia.com/publication/turkey-crushed-uae-gambit-libya/ (Letöltés időpontja: 2020. 11. 29.)

${ }^{61}$ Például az Egyesült Arab Emírségek feltételezett légicsapása török légvédelmi eszközökre az al-Vatíja légibázison. 
folyás korlátok közé szorítása volt. A konfliktusban átmeneti nyugvópontot hozott a két líbiai kormány közötti augusztusi tüzszünet. Ez azonban csak rövid életünek bizonyult, és mindkét fél részéről sokkal inkább a konfliktus további szakaszaira történő felkészülést szolgálta.

A Líbiában bevetett fegyverek számbavételekor hasonlóságok és különbségek is felfedezhetőek a korábbiakban tárgyalt török szerepvállalásokhoz képest.

- Korkut mobil légvédelmi egység: az Aselsan által fejlesztett és gyártott lánctalpas önjáró légvédelmi rendszer kifejezetten a gépesített egységek csapatlégvédelmére szolgál. Érdekesség, hogy a gépágyú löszere is török fejlesztésủ és gyártású (35 mmes airburst ${ }^{62}$ gépágyúlőszer), tehát ez esetben meglehetősen magas szinten teljesül a sokszor áhított importfüggőség kiváltása. A fegyver leghatékonyabban pilóta nélküli repülőeszközök és rakéták ellen vethető be. ${ }^{63}$ Előbbire számos esetben volt példa Líbiában is, mivel az eszközzel több, a keleti kormányhoz vagy valamely külföldi támogatójához tartozó drónt sikeresen megsemmisítettek.

- T-155 Firtina önjáró löveg és T-122 Sakarya rakéta-sorozatvetö: a Szíriában is alkalmazott eszközöket az ellenséges tüzérségi állások és eszközök megsemmisítésére vetették be Líbiában, szintén sikerrel. Az ellenség tüzérségi lövedékeit és állásait bemérő radarokkal összekapcsolva a török tüzérség rendkívül hatékonyan, 30-60 másodpercen belül tudott válaszcsapást kiváltani. A keleti kormány erői erre válaszul még a Kadhafi-érából származó mobil tüzérségi egységeket reaktiválták, és egy ideig sikeresen tudtak ellentevékenységet kifejteni a török erőkkel szemben. Végül azonban a török felfegyverzett drónok megsemmisítették ezeket az eszközöket is.

- Bayraktar TB2 pilóta nélküli repülőeszköz: a felfegyverzett drónt a török haderő a líbiai hadszíntéren is rendkívül magas fokon integrált rendszerben tudta alkalmazni. Nem pusztán a már érintett tüzérségi eszközök lefogása/elpusztítása érdekében, hanem többféle mozgó jármü ellen is sikerrel vetették be, valamint Líbiában is meglepően ellenállónak bizonyult a különféle elektronikai zavarási kísérletekkel szemben.

- Anka S pilóta nélküli repülöeszköz: a felderítődrón elsősorban a Bayraktar TB2 és egyéb fegyveres drónokkal „,müködött együtt”, illetve tüzérségi rávezetésből, klaszszikus megfigyelési és felderítési feladatokból vette ki részét.

- Akıncı pilóta nélküli repülőeszköz: a Baykar által gyártott HALE-kategóriájú ${ }^{4}$ drón egészen új eszköz, ${ }^{65}$ az Altay harckocsihoz hasonlóan még csapatpróbáit teljesíti, ennek keretében vetették be Líbiában is. A korábban már részletezett technikai akadályok és importalkatrészek hiánya miatt csak korlátozott eredményekkel alkalmazták.

- Koral elektronikai hadviselési rendszer: a török légi és szárazföldi (elsősorban tüzérségi) egységek tevékenységét segítette.

- Hisar-A és Hisar-O légvédelmi rakétarendszerek: a Roketsan kis, illetve közepes hatótávolságú lánctalpas légvédelmi rakétarendszerei, a 2020. tavaszi csapattelepítésekkel együtt vetették be őket Líbiában. A Hisar-A a manőverező török szárazföldi alakulatok mobil légvédelmét, ${ }^{66}$ a Hisar-O pedig a fix létesítmények (török elöretolt bázisok, légibázisok, raktárlétesítmények) légvédelmét látta el. ${ }^{67}$

\footnotetext{
${ }^{62}$ Még a cél előtt, a levegőben robbanó repeszhatású lőszer.

${ }^{63}$ Turkish Defense Industry Product Catalogue, 238.

${ }^{64}$ High Altitude Long Endurance - nagy repülési magasságú, hosszú repülési idejű.

65 Turkish Defense Industry Product Catalogue, 144.

66 Uo. 187.

67 Uo. 189.
} 
- TMR-II robot: érdekesség, hogy az Elektroland vállalat által gyártott katonai felhasználású robotokat ${ }^{68}$ a török hadsereg már az ellenörzése alá vont líbiai területeken vetette be, ahol elsősorban improvizált robbanószerkezetek, illetve aknák és más telepített robbanószerek felderítésére és hatástalanítására használta. ${ }^{69}$

A török hadsereg líbiai beavatkozásának nemzetközi megítélése eltér a szíriai hadmüveletek esetében tapasztaltaktól. Míg a szíriai hadmozdulatok és különösen az ország északi részének török ellenőrzés alá vonása különböző gazdasági szankciókat, sőt fegyverembargót eredményezett föleg európai államok részéről, addig a líbiai intervenció ,,mindössze” diplomáciai ellenlépéseket, illetve politikai elítélést váltott ki. Ebben komoly szerepet játszott az Európai Unió egységes álláspontjának látványos hiánya is. Természetesen a török hadiipart sújtó, elsősorban importkorlátozások ugyanúgy érintik a líbiai müveleteket is. ${ }^{70}$ Összességében Törökország egy viszonylag korlátozott létszámú, de magas technológiai színvonalú intervenciós haderővel eddig eredményesen érte el a kitüzött müveleti céljait, komoly ellenlépésekre kényszerítve a másik kormányt támogató külső szereplöket is.

\section{ÉVSZÁZADOS IDEOLÓGIAI SZEMBENÁLLÁS, A TÖRÖK HADITECHNIKA ÚJABB ÉLES PRÓBÁJA - KONFLIKTUS HEGYI-KARABAHBAN}

A török hadiipar térségbeli szerepét vizsgálva utolsó példánk a Kaukázus vitatott hovatartozású területe, Hegyi-Karabah kapcsán kirobbant/kiújult fegyveres konfliktus Azerbajdzsán és Örményország között. 2020 szeptemberében egy régi, hosszú évtizedekre visszanyúló történelmi, etnikai, ideológiai ellentét fajult újólag közvetlen fegyveres konfliktussá az azeri és az örmény fél között. Ebbe a konfliktusba kapcsolódott be újra Törökország az azeri oldalon, ${ }^{71}$ ez alkalommal viszont közvetlen fegyveres segítség formájában.

Bár a török beavatkozás a karabahi konfliktusba viszonylag gyorsan és a külvilág számára meglepő módon és eszközökkel történt, az alább részletezett fegyverek, eszközök és alkalmazott taktikát érintő segítségnyújtás azonban nem volt teljesen előzmény nélküli, ${ }^{72}$ erröl a török-azeri fegyverexport volumenének meredek emelkedése ad árulkodó bizonyítékokat. ${ }^{73}$

${ }^{68}$ Uo. 48.

69 Turkey deploys homemade robots in Libyan battlefields. TRT World, 20. 07. 2020. https:/www.trtworld.com/ turkey/turkey-deploys-homemade-robots-in-libyan-battlefields-38272 (Letöltés időpontja: 2020. 12. 02.)

${ }^{70}$ Raúl Redondo: Outrage in Germany over Turkey's use of German weapons in Libya's war. Atalayar, 25. 06. 2020. https://atalayar.com/en/content/outrage-germany-over-turkeys-use-german-made-weapons-libyas-war; Nicholas Fiorenza: German frigate halts check of Turkish ship suspected of breaking Libya embargo. Janes, 26. 11. 2020. https://www.janes.com/defence-news/news-detail/german-frigate-halts-check-of-turkish-ship-suspected-ofbreaking-libya-embargo (Letöltések időpontja: 2020. 12. 01.)

71 Törökország már évtizedek óta újra és újra beavatkozik a konfliktusba Azerbajdzsán oldalán, bár eltérő volumenben és eszközökkel (pl. pénzügyi, politikai támogatás).

72 Az Azerbajdzsánba irányuló török fegyverexport mértéke ugrásszerü növekedést mutatott 2020 harmadik negyedévében, ami különösen szembeötlő a korábbi évekkel összehasonlítva. Az örmény részröl elhangzott azon vádak azonban, miszerint ez egy teljes mértékben titkos alku eredménye lett volna, véleményem szerint nem teljesen helytállóak, mivel e beszerzések döntő részével kapcsolatban már korábban szerződés köttetett a felek között.

73 Ece Toksabay: Turkish arms sales to Azerbaijan surged before Nagorno-Karabakh fighting. Reuters, 14. 10. 2020. https://www.reuters.com/article/us-armenia-azerbaijan-turkey-arms/turkish-arms-sales-to-azerbaijan-surgedbefore-nagorno-karabakh-fighting-idUSKBN26Z237 (Letöltés időpontja: 2020. 12. 01.) 
A karabahi fegyveres összecsapások során alkalmazott legfontosabb török fegyverek és az alkalmazott taktika, illetve harceljárások:

- Bayraktar TB2 pilóta nélküli repülőeszköz: a szíriai és a líbiai hadszíntereken is alkalmazott eszköz a karabahi hadmüveletek során rendkívül kiemelt szerepet játszott. Szakértők egy része egyenesen a pilóta nélküli légi hadviselés új korszakáról beszél a 2020. őszi hadmüveleteket követően. ${ }^{74}$ Az azeri fél a korábbiakban már jelzett módon, fokozatosan felkészültt ${ }^{75}$ a müveletek megkezdésére hadianyag és fegyverek beszerzése révén. ${ }^{76}$ Minden jel arra mutat azonban, hogy Törökország ezúttal nem pusztán eszközökkel, de az alkalmazott taktikák megosztásával is segítette az azeri haderöt.

- Anka S pilóta nélküli repülöeszköz: a szintén török gyártmányú felderítődrónok a Bayraktar TB2 drónokkal szoros együttmüködésben hajtották végre bevetéseiket az örmény alakulatok és létesítmények ellen.

Az azeri haderö által 2020-ban alkalmazott taktika sokakat meglepett, ugyanis a korábbi fegyveres összecsapásokban nem alkalmaztak korszerű eljárásokat, ráadásul - az örmény hadsereghez hasonlóan - elsősorban volt szovjet, illetve orosz haditechnikai eszközökkel vannak felszerelve. A török Bayraktar drónok bevetését azonban olyan videó- és müholdfelvételek kísérték, melyeken kiégett örmény harcjármüvek, elpusztított elöretolt bázisok és menetoszlopok szerepeltek. Helyszíni beszámolók szerint a drónokat kötelékben vetették be, a felderítő- és csapásmérő egységeket szoros együttmüködésben. ${ }^{77}$ Az azeri haderő ebben az összecsapásban egyértelmü technológiai fölényben volt.

Az egyik legfontosabb tapasztalat a hagyományos szárazföldi alakulatok rendkívüli sérülékenysége a korszerü pilóta nélküli repülőeszközökkel szemben. Ebben egyrészt a régi szovjet technika elavultsága, másrészt pedig az elektronikai ellentevékenység hiánya játszott szerepet. Az örmény páncélozott csapatszállítók, gépesített gyalogsági egységek, sőt még a harckocsi-alakulatok is ${ }^{78}$ tehetetlenek voltak az azeri drónok precíziós csapásaival szemben. Az első néhány nap súlyos veszteségei következtében az örmény alakulatok gyors visszavonulásban hátráltak, rövid idő alatt átengedve azt a védelmi vonalat, amelyet tulajdonképpen az 1990-es évek közepétöl eredményesen tartottak az azeriekkel szemben. ${ }^{79}$ Az azeriek által korszerü NATO-doktrínák gyakorlati alkalmazására került sor, és nem pusztán a pilóta nélküli repülőeszközök bevetése terén. Elemzők szerint az azeri fegyveres erők gyors és pontos csapásokat intéztek a kiemelt örmény célpontok - elsősorban a tüzérségi állások és a telepített légvédelmi rendszerek - ellen, és új elemként a tüzérségi lövegek és rakéta-sorozatvetők is a nagy őrjáratozási idejü felderítődrónok céladatai alapján mérték be

${ }^{74}$ Ron Synovitz: Technology, tactics, and Turkish advice lead Azerbaijan to victory in Nagorno-Karabakh. RadioFreeEurope, 13. 11. 2020. https://www.rferl.org/a/technology-tactics-and-turkish-advice-lead-azerbaijanto-victory-in-nagorno-karabakh/30949158.html (Letöltés időpontja: 2020. 11. 30.)

752020 szeptemberében már Azerbajdzsán volt Törökország legnagyobb fegyvervásárlója, a beszerzett eszközök nagy része lőszer, tüzérségi eszköz, illetve felderítö- és felfegyverzett drónok, valamint az ezek által használt precíziós lőszerek és bombák voltak.

76 Nagorno-Karabakh, Turkish weapons in support of the Azeris in the war with the Armenians. Asianews, 15. 10. 2020. http://www.asianews.it/news-en/Nagorno-Karabakh,-Turkish-weapons-in-support-of-the-Azeris-in-thewar-with-the-Armenians-51308.html (Letöltés időpontja: 2020. 12. 02.)

77 Synovitz: i. m.

${ }^{78}$ Külföldi források szerint az örmény haderő egy hónap leforgása alatt mintegy 175 harckocsit vesztett.

79 Synovitz: i. m. 
és semmisítették meg a célpontjaikat. Korábban ilyen, szinte valós idejü céladatokkal nem tudott dolgozni az azeri tüzérség, és ez óriási hatékonyságnövekedést jelentett. ${ }^{80}$

A másik újdonságot az ellenséges mobil légvédelmi egységek célzott felkutatása és támadása jelentette. Ezek pontos bemérését egyrészt az órákat a célterület felett töltő felderítődrónok segítették elö, valamint a régen elavultnak számító szovjet An-2 típusú kétfedelü szállítógép ,feláldozása”. Ezeket távirányítással vezették a feltételezett örmény légvédelmi egységek közelébe, majd lelövésüket követően a levegőben tartózkodó felfegyverzett Bayraktar drónok - a felderítőgépek adatai alapján - kiiktatták a légvédelmi ütegeket. ${ }^{81}$

Törökország katonai befolyása azonban nem merült ki modern haditechnikai eszközök megosztásában, több esemény azt bizonyítja, hogy korszerü NATO-taktikákat is átadtak az azeri haderő alakulatainak. Nevezetesen a NATO-csapatok afganisztáni - a HegyiKarabahéhoz igen hasonló - hegyvidéki környezetben kialakított, kis létszámú, gyorsan mozgó kisalegységeinek tapasztalatait és harceljárásait alkalmazták az azeri erők is. Miután a dróncsapások megnyitották az örmény védelmi vonalat, az azeriek ezeken a réseken keresztül nyomultak be kis létszámú, gyorsan mozgó alegységekkel örmény területekre. Itt azután örmény létesítmények elleni szabotázsakciókat hajtottak végre, illetve pontos célkoordinátákat szolgáltattak saját légierejük és tüzérségük számára a további csapásmérések sikeressége érdekében. Ezzel a módszerrel el tudták érni, hogy több városból - például Fuzuli (Varanda) és Caybrayil (Jrakan) - és megerődített védelmi állásból szinte harcok nélkül tudták elüzni az örmény erőket. ${ }^{82}$ Szakértők szerint ezeket a harceljárásokat az azeriek nem tudták volna ennyire rövid idő alatt elsajátítani, így egyértelműen a török erőktől ${ }^{83}$ kaptak ilyen irányú kiképzést. Ez a hadművelet volt az első, amikor az azeri erők ilyen mértékben és eredményességgel használták a speciális erőket.

A török eszközök és új harceljárások alkalmazásának ugyancsak fontos következménye volt - a gyors müveleti eredményeken és területi nyereségeken túl - a humán veszteségek csökkentése. A nagy arányban alkalmazott pilóta nélküli eszközöknek és a célzott, korlátozott csapásméréseknek köszönhetően azeri oldalon jóval kisebb veszteségekről beszélhetünk, mint a Hegyi-Karabah területén korábban lezajlott müveletek esetében. ${ }^{84}$ E sikerek következtében Azerbajdzsán jelenleg teljesen uralja a hadszínteret és korlátozott területi nyereségekre is szert tett. Kérdéses, hogy az egyértelmü technikai fölény meddig biztosítja ezt az előnyt, illetve Törökországon kívül más külső szereplők mikor avatkoznak be hasonló módon az azeri-örmény konfliktusba.

${ }^{80}$ Fuad Shahbazov: Tactical reasons behind military breakthrough in Karabakh conflict. The Jamestown Foundation, 03. 11. 2020. https://jamestown.org/program/tactical-reasons-behind-military-breakthrough-in-karabakh-conflict/ (Letöltés időpontja: 2020. 11. 29.)

${ }^{81}$ Robin Forestier-Walker: Nagorno-Karabakh: New weapons for an old conflict spell danger. Al Jazeera, 13. 10. 2020. https://www.aljazeera.com/features/2020/10/13/nagorno-karabakh-new-weapons-for-an-old-conflict-spelldanger (Letöltés időpontja: 2020. 12. 03.)

${ }^{82}$ Ridvan Bari Urcosta: Drones in Nagorno-Karabakh. Small Wars Journal, 23. 10. 2020. https://smallwarsjournal. $\mathrm{com} / \mathrm{jrnl} /$ art/drones-nagorno-karabakh (Letöltés időpontja: 2020. 11. 29.)

${ }^{83}$ Ehhez hozzájárulhatott az is, hogy a török haderő aktív szerepet játszott az ISAF afganisztáni mủveleteiben, ahol e téren közvetlen tapasztalatokkal rendelkeztek.

${ }^{84}$ Dorian Jones: Will Turkish-made drones give Azerbaijan the edge in Nagorno-Karabakh? Radio France International, 21. 10. 2020. https://www.rfi.fr/en/podcasts/international-report/20201021-will-turkish-made-drones-giveazeris-the-edge-in-battle-for-nagorno-karabakh (Letöltés időpontja: 2020. 11. 28.) 


\section{KÖVETKEZTETÉSEK}

Megállapítható, hogy Törökország és a török hadiipar igen jelentős befolyással bír a térségbeli katonai események menetére. Az írásban bemutatott három konkrét fegyveres konfliktus esetében a részt vevő felek felkészültségét, fegyveres alakulataik felszereltségét közvetlenül is befolyásolja a beszerzett és alkalmazott török fegyverek megléte. Egyes esetekben pedig - mint a karabahi konfliktusban tevékenykedő azeri erök esetében - ez a befolyás nem pusztán eszközökben, fegyverekben, de az alkalmazott harceljárásokban, taktikai elemekben is megnyilvánul. Megítélésem szerint ez pedig már egy magasabb szintű török ráhatást jelent a harcokra, mint ahogy az a legtöbb hasonló, külső aktorok által befolyásolt fegyveres konfliktus esetében eddig látható volt.

\section{FELHASZNÁLT IRODALOM}

Arms exports (SIPRI trend indicator values) - Turkey. The World Bank, 2020. https://data.worldbank. org/indicator/MS.MIL.XPRT.KD?locations=TR

Bilgrami, Mohammad Pervez: How Turkey crushed UAE's gambit in Libya. Agenfor International, 01. 06. 2020. https://www.agenformedia.com/publication/turkey-crushed-uae-gambit-libya/

Côrte Réal-Pinto, Anouck Gabriela: A Neo-Liberal Exception? The Defence Industry 'Turkification'Project. Revue international de politique de développement, 8/2017., 299-331. https://journals.openedition. org/poldev/2456

Côrte Réal-Pinto, Anouck Gabriela: Une exception néolibérale? Le projet de turquification de l'armement. Revue international de politique de développement, 08. 09. 2017. https://journals.openedition.org/ poldev $/ 2456$

Fiorenza, Nicholas: German frigate halts check of Turkish ship suspected of breaking Libya embargo. Janes, 26. 11. 2020. https://www.janes.com/defence-news/news-detail/german-frigate-halts-checkof-turkish-ship-suspected-of-breaking-libya-embargo

Forestier-Walker, Robin: Nagorno-Karabakh: New weapons for an old conflict spell danger. Al Jazeera, 13. 10. 2020. https://www.aljazeera.com/features/2020/10/13/nagorno-karabakh-new-weaponsfor-an-old-conflict-spell-danger

Gurini, Ferhat: Turkey's unpromising defense industry. Carnegie Endowment for International Peace, 09. 10. 2020. https://carnegieendowment.org/sada/82936

How Turkey became one of the world's leading manufacturers of weapons systems. Defense News, 21. 07. 2020. https://www.defensenews.com/native/turkish-defence-aerospace/2020/07/21/howturkey-became-one-of-the-worlds-leading-manufacturers-of-weapons-systems/

Huszák Dániel: Bejelentették: több mint 300 újfajta katonai jármüvet szerez be a Honvédség. Portfolio, 2020. 12. 21. https://www.portfolio.hu/global/20201221/bejelentettek-tobb-mint-300-ujfajta-katonaijarmuvet-szerez-be-a-honvedseg-462752

Huszák Dániel: Vadi új katonai jármüvek gyártása indul meg Magyarországon. Portfolio, 2020. 12. 18. https://www.portfolio.hu/global/20201218/breking-vadi-uj-katonai-jarmuvek-gyartasa-indul-megmagyarorszagon-462484

Jones, Dorian: Will Turkish-made drones give Azerbaijan the edge in Nagorno-Karabakh? Radio France International, 21. 10. 2020. https:/www.rfi.fr/en/podcasts/international-report/20201021-willturkish-made-drones-give-azeris-the-edge-in-battle-for-nagorno-karabakh

Magyar helyett török harcjármüveket vásárolt a honvédség. Totalcar, 2020. 10. 31. https://totalcar.hu/ magazin/hirek/2020/10/31/magyar_helyett_torok_harcjarmuveket_vasarolt_a_honvedseg/ 
Nagorno-Karabakh, Turkish weapons in support of the Azeris in the war with the Armenians. Asianews, 15. 10. 2020. http://www.asianews.it/news-en/Nagorno-Karabakh,-Turkish-weapons-in-supportof-the-Azeris-in-the-war-with-the-Armenians-51308.html

Nathan, Adam: Cargo ship loaded with Turkish military vehicles arrives in Tripoli. Alarabiya News, 20. 05. 2020. https://english.alarabiya.net/News/north-africa/2019/05/19/Cargo-ship-loaded-withTurkish-military-vehicles-arrives-in-Tripoli

Redondo, Raúl: Outrage in Germany over Turkey's use of German weapons in Libya's war. Atalayar, 25. 06. 2020. https://atalayar.com/en/content/outrage-germany-over-turkeys-use-german-madeweapons-libyas-war

Rodriguez, Ana: Turkey shows military muscle in Syria with the shipment of 35 new military vehicles. Atalayar, 05. 05. 2020. https://atalayar.com/en/content/turkey-shows-military-muscle-syriashipment-35-new-military-vehicles

Shahbazov, Fuad: Tactical reasons behind military breakthrough in Karabakh conflict. The Jamestown Foundation, 03. 11. 2020. https://jamestown.org/program/tactical-reasons-behind-militarybreakthrough-in-karabakh-conflict/

Synovitz, Ron: Technology, tactics, and Turkish advice lead Azerbaijan to victory in Nagorno-Karabakh. RadioFreeEurope, 13. 11. 2020. https://www.rferl.org/a/technology-tactics-and-turkish-advicelead-azerbaijan-to-victory-in-nagorno-karabakh/30949158.html

Tekingunduz, Alican: Turkey's growing defence industry. TRT World, 04. 05. 2018. https://www.trtworld. com/turkey/turkey-s-growing-defence-industry-17014

Toksabay, Ece: Turkish arms sales to Azerbaijan surged before Nagorno-Karabakh fighting. Reuters, 14. 10. 2020. https://www.reuters.com/article/us-armenia-azerbaijan-turkey-arms/turkish-armssales-to-azerbaijan-surged-before-nagorno-karabakh-fighting-idUSKBN26Z237

Turkey among top 100 in global arms industry. TRK World, 11. 12. 2018. https://www.trtworld.com/ turkey/turkey-among-top-100-in-global-arms-industry-22395

Turkey deploys homemade robots in Libyan battlefields. TRT World, 20. 07. 2020. https://www.trtworld. com/turkey/turkey-deploys-homemade-robots-in-libyan-battlefields-38272

Turkey records significant drop in defense industry exports in January-August 2020. Nordic Monitor, 25. 09. 2020. https://nordicmonitor.com/2020/09/turkey-records-significant-drop-in-defenceindustry-exports-in-january-august-2020/

Turkey's Strategic Vision 2023 Project. TASAM, 2012. http://www.tsv2023.org/index.php/en/

Turkey tops the international weapon export rating. TRT World, 12. 03. 2019. https://www.trtworld. $\mathrm{com} /$ turkey/turkey-tops-the-international-weapon-export-rating-24880

Turkish Army makes major military deployment to Syria's Idlib. Daily Sabah, 16. 10. 2020. https:// www.dailysabah.com/world/syrian-crisis/turkish-army-makes-major-military-deployment-to-syriasidlib?gallery_image=undefined\#big

Turkish Defense Industry Product Catalogue. Presidency of Defense Industries, Ankara, 2019. https:// www.ssb.gov.tr/urunkatalog/en/

Turkish-Indonesian relations deepen with defense industry cooperation. Nordic Monitor, 13. 11. 2020. https://nordicmonitor.com/2020/11/turkey-indonesia-relations-deepen-with-defense-industrycooperation/

Turkish military arsenal in Syria. Jusoor for studies, 02. 03. 2020. https://jusoor.co/details/Turkish\%20 Military\%20Arsenal\%20in\%20syria/584/en

Urcosta, Ridvan Bari: Drones in Nagorno-Karabakh. Small Wars Journal, 23. 10. 2020. https:// smallwarsjournal.com/jrnl/art/drones-nagorno-karabakh 